\title{
FORMAÇÃO DOCENTE EM CAMPO: UMA EXPERIÊNCIA \\ PEDAGÓGICA E FRUITIVA DA GALERIA DE ARTE À SALA DE
}

AULA

\author{
TEACHER TRAINING IN THE FIELD: AN EDUCATIONAL \\ EXPERIENCE AND FRUITIVE ART GALLERY TO THE \\ CLASSROOM
}

DOI: http://dx.doi.org/10.5965/1984317813012017033

André Camargo Lopes, Renan dos Santos Silva, Thais Doro, André Hamada Kikumoto, Stephanie Ortiz Conselvan, Vinícius Bardi Castilho - UNESP

\begin{abstract}
RESUMO
Este artigo é a sistematização de uma unidade das ações coformadoras de iniciação à docência, efetivada dentro do Programa de Bolsas de Iniciação à Docência - PIBID/UEL e em parceria com o CE Prof. ${ }^{a}$ Roseli Piotto Roehrig - Localizada na zona norte de Londrina, PR; donde toma-se por empréstimo as sínteses narrativas dos Professores em Formação, oriundas de seus relatos e planos de atividades e estes das narrativas dos alunos da escola, bem como os registros e observações. Neste sentido, a unidade a que mencionamos, se refere a uma experiência de aprendizado à docência dentro da própria prática pedagógica; onde Professores em Formação, orientados e acompanhados pelo Professor Coformador, implementam "Processos de Ensino" aos níveis possíveis de vivência e amadurecimento estético e pedagógico a partir de um eixo para as aulas: a experiência da "Fruição", decorrentes de uma exposição de arte contemporânea, realizada na Galeria da Divisão de Artes Plásticas da UEL. Estes propósitos concatenados caminham por dois vetores convergentes: o Professor Coformador toma como suporte metodológico o "raciocínio reflexivo" sobre o fazer em arte em experiência-aulas. Proporcionam aos Alunos da Escola apropriações dos saberes em arte através da vivência fruitiva e, aqueles, os Iniciantes Docentes à apropriação dos saberes pedagógicos.
\end{abstract}

PALAVRAS-CHAVE: Ensino de Arte Visual. Formação Docente. Mediação Pedagógica.

\begin{abstract}
This article is the systematization a unit of shares coforming the introduction to teaching, effected within the Initiation Scholarship Program to Teaching - PIBID/UEL and in partnership with CE Prof. ${ }^{\text {a }}$ Roseli Piotto Roehrig - Located in the north of Londrina, PR; where is taken on loan syntheses narratives of Teachers in Training, derived from their accounts and activities of these plans and the narratives of school students, as well as the records and observations.. In this sense, the unit to which we mentioned, refers to a learning experience to teaching within the teaching practice; where teachers in training, guided and accompanied by Coforming Teacher, implement "Learning Process" to possible levels of experience and aesthetic and educational maturation from an axis for classes: the experience of "Fruition", resulting from a contemporary art exhibition held in the gallery of the Division of Plastic Arts of the UEL. These concatenated purposes walk by two converging vectors: the Coforming Teacher takes as methodological support the "reflective thinking" about doing art experience - classes. To provide students of the School its wisdom in art through fruitive experience and, those, Beginners Teachers to the appropriation of pedagogical knowledge .
\end{abstract}




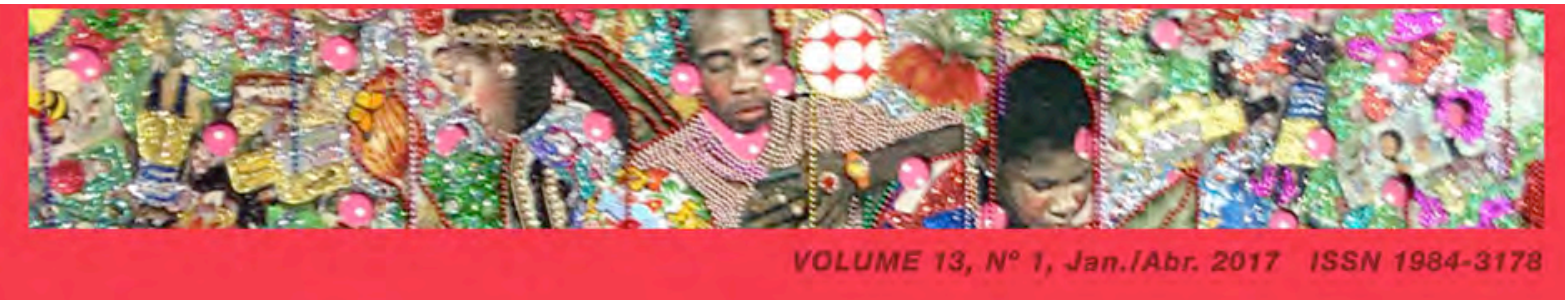

KEYWORDS: Visual Art Education. Teacher Training . Pedagogical mediation.

\section{INTRODUÇÃO}

As Diretrizes Curriculares do Estado do Paraná (2008) orientam aos professores de Arte a organizarem os conteúdos relacionando-os com a realidade do aluno e de seu entorno, ou seja, os orienta a partir de seus referenciais culturais, embora tal perspectiva por mais concreta e regionalista que seja, tende ao reducionismo, pois nessas orientações não há indagação de "quais seriam esses referenciais culturais?"

As orientações, no entanto, ao referirem a uma arte regional, ignora que os referenciais artísticos mais próximos da maioria dessas crianças e jovens são os globais, amplamente veiculados pela indústria cultural.

Tais impasses na organização dos conteúdos colocam em relevo uma das bases do ensino de Arte que muitas vezes é negligenciada: a fruição. Desta forma, não se busca a vivência estética diversificada, ao contrário, reduz ao possível, ao imediato.

No ensino de Arte na Educação Básica, pelo menos três pilares sustentam uma boa compreensão da dinâmica para a apropriação das linguagens e seus códigos. São eles contextualização, fruição e a produção. Geralmente nos atentamos - muitas vezes devido às condições de trabalho, formação e interesse - à contextualização, tornando o ensino de Arte uma ramificação cultural da disciplina de História, ou então, enfatiza-se o fazer, explorando no aluno a repetição de padrões, sejam eles mentais ou esquemáticos fornecidos pelo próprio professor, sem a devida problematização, consequentemente, sem a experiência criativa. É inegável a importância de cada um destes pilares para o ensino de Arte, porém, nenhum deles se sustenta sozinho, são complementares, e essa compreensão deve estar presente na formação do professor de Arte. Logo, contextualização, fruição e produção são indissociáveis.

Neste texto procurar-se-á expor a partir do processo de ensino, os níveis possíveis de vivência e amadurecimento estético-pedagógico, vivenciados por professores em formação do Programa Institucional de Bolsas de Iniciação à Docência (PIBID) e alunos da Rede Básica de ensino a partir da experiência fruitiva desenvolvida na galeria da Divisão de Artes Plásticas 


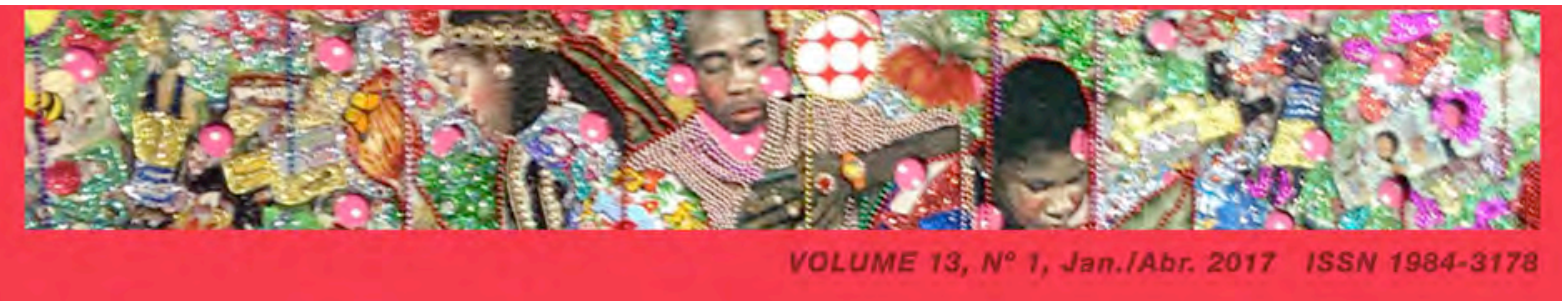

da Universidade Estadual de Londrina ${ }^{1}$. Abordar-se-á as etapas de construção de um raciocínio reflexivo sobre o fazer em arte em uma experiência-aula com turmas de primeiro ano do Ensino Médio e a ação mediadora como experiência docente em alunos de Licenciatura em Artes Visuais.

Neste sentido, o presente texto procurará responder algumas indagações presentes nesta proposta de aula, tanto na perspectiva da apropriação de saberes dos alunos da educação básica envolvidos na ação, quanto nos alunos de graduação atuantes no espaço como professores em formação (PIBID):

- $\quad$ Em relação à fruição, como conduzir esse contato a um ato significativo diante do processo de ensino-aprendizagem?

- $\quad$ A importância da mediação à apropriação, pelos alunos, dos códigos visuais expostos nas obras de Arte e, consequentemente, à ação criadora nas releituras, vista por professores em formação.

- $\quad$ Como os alunos se apropriam dos códigos das Artes Visuais em seus trabalhos de releitura, e quais elementos agregam a esses na criação de seus trabalhos?

\section{OS INDIVÍDUOS ENVOLVIDOS NO PROCESSO}

Entre os documentos curriculares e a construção dos saberes em Arte, existe uma lacuna a ser preenchida à condição significativa do saber escolar a todos os indivíduos envolvidos neste processo, que é atravessada pela formação do professor. Especificamente no campo da Arte, esse professor deve voltar-se para o diálogo reflexivo e não reducionista.

Através desta problematização inicial pretende-se relatar a experiência desenvolvida no ano de 2016 a partir da parceria entre o Programa Institucional de Bolsa de Iniciação à Docência (PIBID) vinculado à Universidade Estadual de Londrina e o Colégio Estadual

\footnotetext{
${ }^{1}$ Entre os meses de abril e maio de 2016, a galeria da Divisão de Artes Plásticas da Universidade Estadual de Londrina (localizada à Avenida Juscelino Kubitscheck, 1973 - Centro, Londrina - PR) expôs um conjunto de obras sob o tema "Sobre o que pode ser familiar". Foram expostas obras dos artistas Lucas Alameda, Christina Zozerto, Adriel Visoto, Anne Courtois, Bruno Novelli, Claudia Briza, David Almeida, Efe Godoy, João Oliveira, Leandro Muniz, Maristela Cabello, Pedro Ermel, Sheila Ortega e Wagner Pinto. Neste período, foram organizadas visitas com mediação para alunos do ensino básico.
} 
Professora Roseli Piotto Roehrig (localizado no Conjunto Habitacional José Giordano, na zona norte do município de Londrina - PR) e como a presença do Programa dentro da escola é significativa para o amadurecimento da experiência pedagógica do licenciando a partir do convívio direto com a criança e adolescente nas condições em que o processo de aprendizagem se estrutura ${ }^{2}$.

O Programa Institucional de Bolsas de Iniciação à Docência tem como objetivo propiciar essa vivência ao aluno de Licenciatura, dentro da escola, desde os anos iniciais de sua vida acadêmica ${ }^{3}$. O programa se desdobra a partir de um sistema tutorial, no qual os indivíduos envolvidos são dispostos em uma rede hierárquica - coordenador do curso, supervisor e professores em formação -, procura-se desenvolver uma formação acompanhada, em que o futuro docente é orientado dentro do espaço escolar por seu supervisor.

Neste sentido, são apensados dentro do texto, o processo de construção das releituras das obras nas quais tiveram contato. Essas observações serão apontadas através de trechos dos relatórios dos professores em formação e de observações sobre o conjunto de percepções destes, expondo a compreensão que os mesmos desenvolveram do processo de ensino propositor pautados na seguinte estruturação:

Tabela I - estruturação do processo de ensino-aprendizagem

\begin{tabular}{l|l|lc} 
Fruir/apropriar & $\begin{array}{l}\text { Estar diante do objeto de arte, refletir sobre } \\
\text { seus códigos }\end{array}$ & $\begin{array}{l}\text { Ação subjetiva de escolha pessoal do } \\
\text { aluno }\end{array}$ \\
\hline Ação propositora & $\begin{array}{l}\text { A condição de mediador entre o espaço, os } \\
\text { objetos e os múltiplos olhares que se lançam } \\
\text { no contato }\end{array}$ & $\begin{array}{l}\text { O professor atuando como um } \\
\text { problematizador } \\
\text { estimulando a reflexão }\end{array}$ \\
\hline $\begin{array}{l}\text { Ver-se como indivíduo } \\
\text { ativo no processo }\end{array}$ & $\begin{array}{l}\text { Alunos e professores, reconstroem as obras, } \\
\text { partem da proposta inicial do artista para seus } \\
\text { referenciais }\end{array}$ & $\begin{array}{l}\text { A reorientação dos signos e a } \\
\text { obra }\end{array}$ \\
\hline
\end{tabular}

Fonte da tabela: PIBID/André Camargo Lopes

\footnotetext{
${ }^{2}$ A colaboração entre o PIBID-UEL e o Colégio Estadual Professora Roseli Piotto Roehrig, iniciou no segundo semestre de 2012, com um supervisor na Disciplina de Arte e oito professores em formação. A proposta de estudo encaminhada ao colégio remeteu-se a seguinte perspectiva de ensino: como implementar os conceitos da Arte contemporânea dentro da prática do ensino de Arte. Atualmente cinco professores em formação atuam no colégio, divididos em grupos de trabalho no turno de aula das turmas do primeiro ano do Ensino Médio (nas quartas-feiras de manhã) e no contraturno, as quartas e quintas-feiras.

${ }^{3}$ Em 2015 as experiências-aulas foram deslocadas do contraturno para os turnos de aula também, com o objetivo de centrar as reflexões dos professores em formação à realidade de sala de aula. Neste novo estágio de ação, todas as propostas e reflexões sobre o fazer pedagógico foram direcionados pelo Plano de Trabalho Docente do professor de sala regular, criando a necessidade do debate constante sobre método e resultados. As atividades desenvolvidas pelos professores em formação correspondem desde a observação à regência orientada das aulas. O principal aspecto nesta proposta é a participação direta dos professores em formação na elaboração dos planos de aula. Esses planos são retomados nas horas atividades do dia, o que viabiliza uma troca de leituras da mesma experiência de aula, possibilitando um amplo debate favorecedor de revisão das experiências metodológicas.
} 
Neste processo, o professor encontra-se entre duas etapas complementares no ensinoaprendizagem, é um problematizador, logo, um elemento ativo na construção do conhecimento gerado pelo contato: galeria-alunos, galeria-obras-alunos e alunos-obrasgaleria. Responsável pelos debates que antecedem o contato e o debate reflexivo, princípio necessário para a ação criadora sobre a experiência. Nesta perspectiva, tendo o professor o papel de mediador entre o aluno e o mundo (um organizador, estimulador, questionador e aglutinador) conduzindo-o através de seu desenvolvimento cognitivo. Visto assim, em Educação, a Arte é a disciplina que melhor responde a essa expectativa de aprendizagem, sendo por excelência um filtro de experiências entre o indivíduo e o mundo.

\begin{abstract}
A arte, como uma linguagem aguçadora de sentidos, transmite significados que não podem ser transmitido por nenhum outro tipo de linguagem como a discursiva e a científica. O descompromisso da arte com a rigidez dos julgamentos que se limitam a decidir o que é certo e o que é errado estimula o comportamento exploratório, válvula propulsora do desejo de aprendizagem. Por meio da arte é possível desenvolver a percepção e a imaginação para apreender a realidade do meio ambiente, desenvolver a capacidade crítica, permitindo analisar a realidade percebida e desenvolver a criatividade de maneira a mudar a realidade que foi analisada. (BARBOSA, 2008, p. 21)
\end{abstract}

Barbosa (2008, p. 18), na Proposta Triangular afirma que o conhecimento da Arte se dá ao lado da prática com o conhecimento das linguagens artísticas. A Proposta salientou a importância da interpretação no exercício de aprendizagem, enfatizando, assim, o contato com a obra e as possibilidades de explora-la. É uma abordagem metodológica em aprendizagem centrada nos mecanismos de apreciação e criação, e não apenas no produtor. A História da arte ganha neste processo, o caráter de contexto, dentro de novos contextos na decodificação da obra e de seus sentidos.

Nesta perspectiva de trabalho formativo do professor, esses são estimulados a pensarem o processo educacional dentro de suas ações complementares, enfocando a experiência em uma dinâmica simples e tripartida:

a) introdução - contextualização, fruição dos elementos estruturantes básicos e debate problematizador; 
b) desenvolvimento prático - fruição, argumentação, seleção e produção;

c) reflexão/avaliação: debate mediado pelos conceitos de produção e os sentidos que os alunos estabeleceram aos objetos.

Essa metodologia para o trabalho formativo parte do pressuposto que o ensinar é uma construção resultante do constante aprendizado dentro da própria prática pedagógica. Sendo assim, os professores em formação nesse processo, são expostos constantemente ao cronograma de um ciclo reflexivo que se divide em quatro etapas: a) organização dos conteúdos - a partir dos estudos das Diretrizes Curriculares da disciplina; b) estudos e sistematização dos referenciais da proposta de trabalho; c) desenvolvimento, aplicação e retomada das metodologias de ensino; d) reorientações das atividades frente às respostas dos alunos. Essas etapas se complementam, e todo o processo formativo ocorre em contato direto com o aluno. Os resultados desta experiência de ensino-aprendizagem viabilizam um mapeamento da prática docente em seu viés mais problematizante: a receptividade na aprendizagem ${ }^{4}$. Isso fica evidente no relatório do professor em formação André H. Kikumoto:

\begin{abstract}
Nos dividimos em grupos menores para tentamos orientar o processo inteiro de cada aluno, já que esta atividade possuía uma dificuldade maior de compreensão.

"Quando eu vi essa obra, acho que o artista quis falar sobre as coisas que a gente tem e não dá valor. Mas desenhando um por um ele percebeu esses objetos."

Esta é uma fala da aluna T., que escolhera a obra (aquela com várias páginas de sketchbook com desenhos de objetos). Diferentemente dos demais alunos que a interpretaram como uma representação de objetos do cotidiano, a estudante pode questionar, mesmo que ingenuamente, a desvalorização do ser e a constante "necessidade" por novidades que a sociedade atual impõe. Com essa ideia em mãos, iniciamos a escolha do veículo que utilizaríamos e como problematizaríamos esse assunto. Por fim, realizamos lambe-lambes na área externa da escola, com a frase "No que você dá valor?", indagando uma pergunta sem necessidade de resposta, a fim de questionar $o$ observador.
\end{abstract}

Uma proposta de ensino significativo envolve as duas partes do trabalho no ensinoaprendizagem: o professor e os alunos. Em momento algum o professor está centrado no

\footnotetext{
${ }^{4} \mathrm{O}$ aluno de graduação ao entrar em contato com a realidade escolar será confrontado com um conjunto de complexidades que envolvem a rotina de um professor. Isso perpassa desde o desinteresse, a indisciplina, o mau planejamento de aulas (ou a sua ausência), a falta de recursos físicos (espaços apropriados para o desenvolvimento de determinadas práticas educacionais) e materiais (como a falta de materiais básicos - lápis de cor, lápis grafite, etc.), os déficits de aprendizagem, a falta de acompanhamento familiar, as particularidades emocionais de crianças e jovens e a repetência. Esses fatores são determinantes no planejamento do plano de trabalho docente, e especificamente, no caso dos professores em formação, o plano de aula.
} 
conhecimento externo; aquilo que o aluno conseguiu apreender do contato com a exposição artística, por exemplo. Assim como, não negligencia os conteúdos problematizadores por trás da proposta e, por sua vez, envolve o professor, no processo de aprendizagem do aluno, flexibiliza a sua capacidade de compreender e avaliar os resultados de suas propostas, à medida que desenvolva o ofício compreendendo o seu papel de pesquisador e educador.

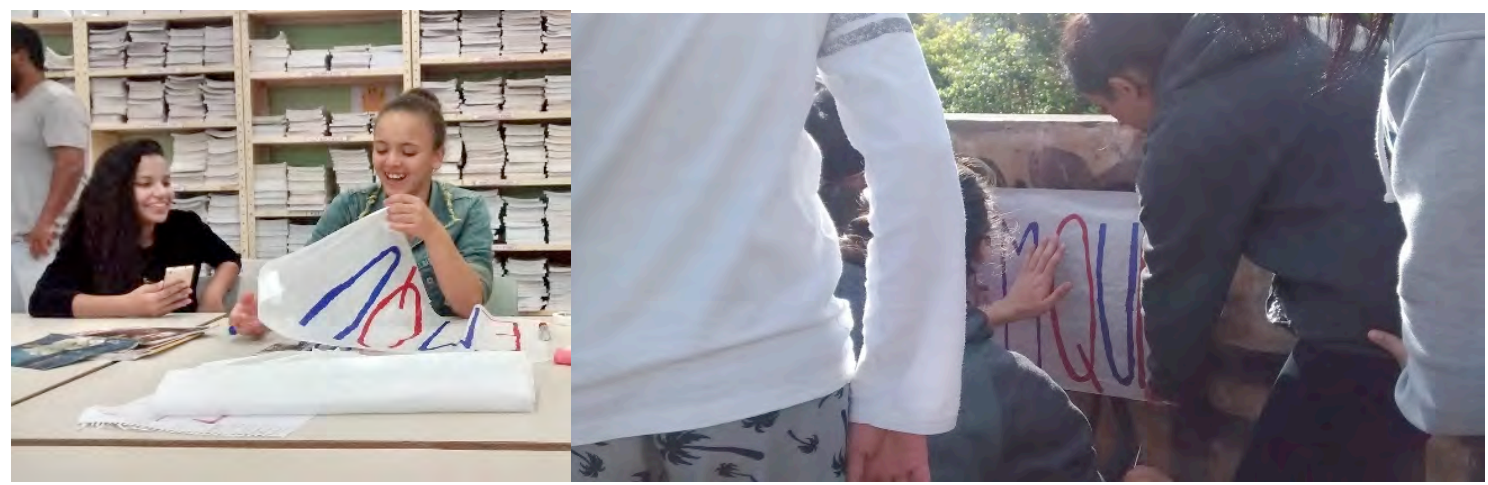

Fontes das imagens: PIBID-ARTES VISUAIS/ UEL

O professor, neste sentido, é visto como um pesquisador em sala que estuda o padrão de aprendizagem, assim como o aspecto comportamental de cada uma de suas turmas. Esse modelo de observação é orientado desde as primeiras reuniões de estudos entre o professor coformador e professores em formação, que corresponde a primeira etapa de estudos do plano de aula, e estudar cotidianamente as respostas do grupo de alunos, e as respostas individuais destes a cada etapa das aulas.

É evidente que o desenvolvimento de ações em contraturno, com o número reduzido de alunos em grupos mediados por um professor em formação (aproximadamente de cinco a dez alunos por professor) essa ação se torne mais perceptível. Porém, o desenvolvimento deste olhar mesmo que em grupos menores, favorece na prática de sala de aula à reflexão voltada para as "aprendizagens" ocorridas, promovendo o deslocamento e a aproximação individual ou em grupos de alunos.

A proposta de aula resultante deste tipo de observação retoma sempre aos pontos positivos e negativos da aula que a precedeu. Logo, o conteúdo não é aplicado por ele mesmo. 


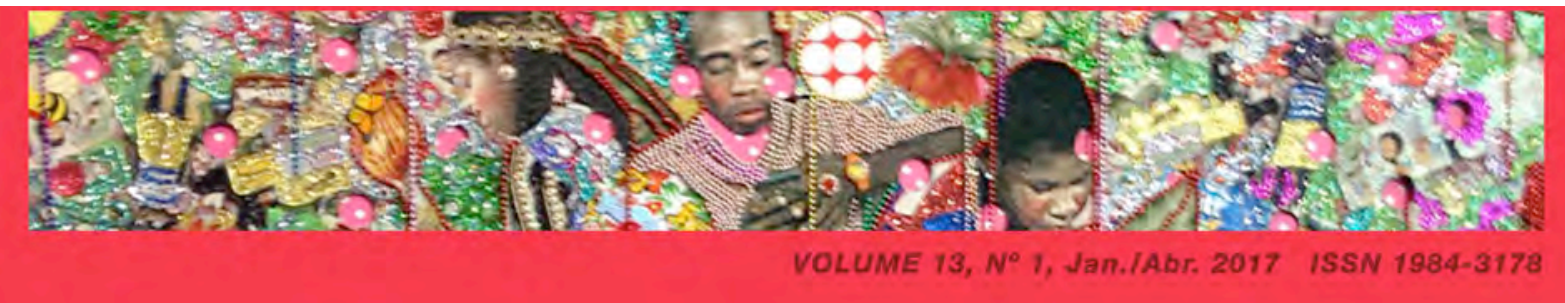

Esse deve fazer parte de um quadro significativo de proposições, compete ao professor estudar essas relações entre o conteúdo científico, estético e artístico, e a sua condução pedagógica. Neste estudo ouvir e ver são ferramentas essenciais.

A proposta de ensino significativo, em cada experiência-aula, coloca ao professor desafios de ordem pedagógica. Questionamentos sobre os objetivos que se tem ao ensinar, bem como o que se pretende como resultado da proposta de ensino.

\section{O OLHAR DO PROFESSOR EM FORMAÇÃO COMO MEDIADOR NO PROCESSO ENSINO APRENDIZAGEM}

O conhecimento produzido nas artes visuais é originário de um processo de produção e reflexão estética sobre o mundo no qual estamos inseridos, o que implica em um envolvimento cognitivo da ação perceptível e sensível entre o indivíduo e as formas resultantes deste contato em imagens. A produção destas imagens, principalmente, as que reflitam algum tipo de relação estética com o mundo revela a necessidade de construção e vivências de referenciais imagéticos no processo de formação educacional deste olhar estético. Essa processualidade construtiva é necessária à medida que o próprio princípio do ensino de Arte na escola volta-se para a natureza cognitiva do olhar, ouvir e sentir.

\footnotetext{
Ver significa essencialmente conhecer, perceber pela visão, alcançar com a vista os seres, as coisas e as formas do mundo ao redor. A visualização ocorre em dois níveis principais. Um deles se refere ao ser que está vendo, com suas vivências, suas experiências. O outro é o que a ambiência lhe proporciona. Mas ver não é só isso. Ver é também um exercício de construção perceptiva onde os elementos selecionados e o percurso visual podem ser educados. (...) Observar é olhar, pesquisar, detalhar, estar atento de diferentes maneiras as particularidade visuais, relacionando-as entre si (FERRAZ e FUSARI, 2010, p. 76).
}

Nesta construção perceptiva são inevitáveis as nuances na relação processual da construção do olhar enquanto experiência e conhecimento visual. A respeito desta característica da educação visual, Bruno Munari (s/d) afirma que cada um vê aquilo que sabe. Ou seja, os códigos visuais estão diretamente relacionados ao conhecimento que o indivíduo tem das realidades que os rodeiam. A construção do olhar possibilita uma expansão do horizonte perceptivo, a captação das coisas em suas estruturas, enxergar além das superfícies 
cotidianas, “(...) Cada coisa que o olho vê tem uma estrutura de superfície própria e cada tipo de sinal, de granulosidade, de filamento, tem um significado bem claro" (MUNARI, apud FERRAZ e FUSARI, 2010, p. 78).

Contribuem para o desenvolvimento do olhar as atividades de leitura visual e história da arte que somadas a constante produção visual dos alunos, possibilitam-nos exercitar e analisar estes modos de ver no próprio processo de aprendizagem, ampliando as potencialidades de domínio da visualidade e da comunicação visual no cotidiano escolar e consequentemente social, ou seja, o ato de contextualizar.

$\mathrm{Na}$ formação dos professores, é indispensável que estes compreendam as subjetividades que constituem a aprendizagem, e, consequentemente, estabeleçam relações entre os elementos visuais da composição de seu cotidiano e a reorientação do sentido estético resultante do contato entre o indivíduo e a experiência vivenciada com a obra de arte estabelecendo neste contato uma mediação entre os elementos estruturantes da linguagem dos artistas e dos períodos abordados, e mesmo que rudimentarmente estabeleçam relação entre aquilo que se vê e aquilo que se entende.

\section{O CONTEXTUALIZAR E SUA APLICABILIDADE}

Por estarem interligadas pelo Plano de Trabalho Docente da Disciplina, as aulas regulares e as experiências-aulas no contraturno dialogaram com o mesmo tema - sendo assim, artistas, contextos e códigos foram trabalhados e aprofundados durante os encontros. $\mathrm{O}$ diálogo mediado possibilitou que os conteúdos da sala de aula servissem como estrutura teórico-plástica na concretização prática das intervenções - sejam elas em vídeo (através de vídeo performances), in loco (como nos happenings desenvolvidos durante os intervalos dos alunos da escola no vespertino), ou pelo entorno do colégio (intervenções com lambe-lambe realizadas por alguns alunos). 


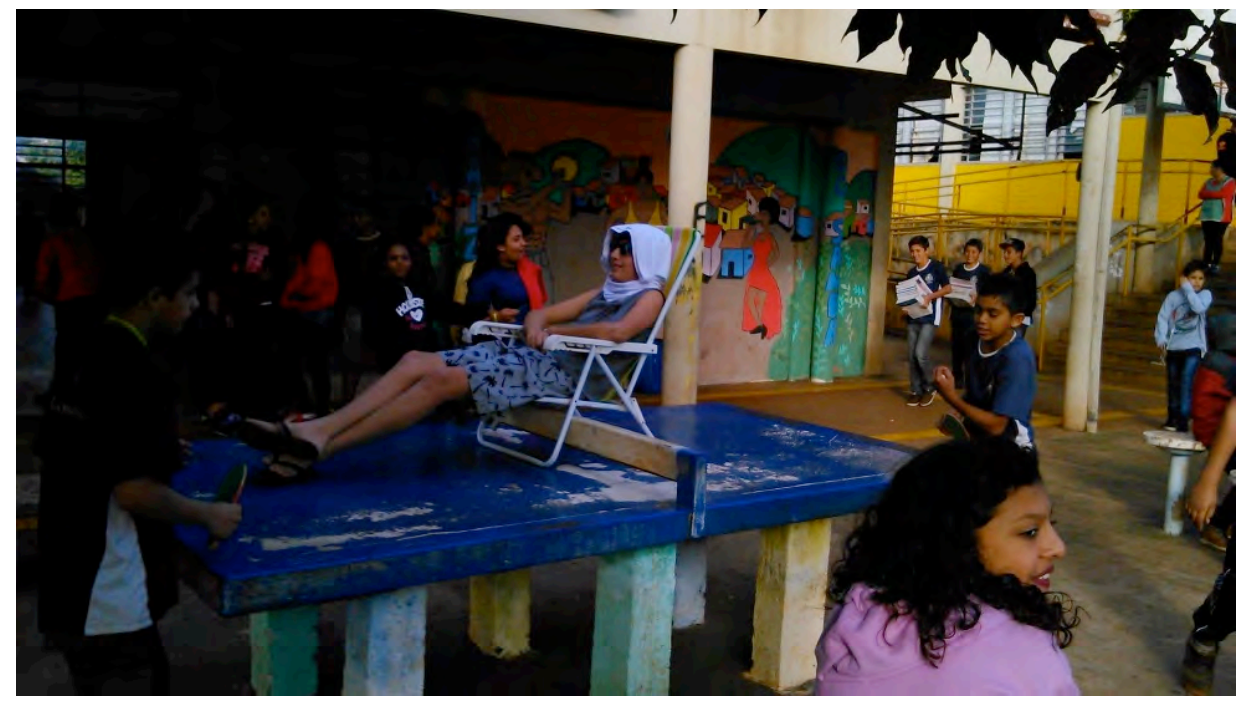

Fonte da imagem: PIBID-ARTES VISUAIS/ UEL

\begin{abstract}
Imagem 02 - Happening a partir da série "Onde descansa a minha alma" (2015), de Bruno Novelli. O aluno em trajes doméstico conduziu sua cadeira de descanso nos mais diversos espaços do Colégio, especificamente os de uso esportivo, a quadra e a mesa de pingue pongue.
\end{abstract}

Cada elemento conceitual foi exposto a partir de sua própria problematização. A priori os alunos foram orientados a refletir sobre os códigos presentes nas obras abordadas durante a visita à DAP/UEL, a partir de seu juízo de valor imediato, sem a mediação explicativa. Essa experiência ocorreu ainda dentro da DAP/UEL, sendo retomada em sala de aula e posteriormente, nos quatro encontros de contraturno.

Nesta perspectiva, primeiro dia da experiência-aula foi dedicado a um mapeamento diagnóstico da aprendizagem dos alunos (repassado para o professor pelas fichas de controle dos professores em formação) somado a uma retomada pontual da leitura realizada pelos mesmos, da obra de cada artista elencado. Nesse estágio o uso de imagens fotográficas e as fichas utilizadas durante a visita foram indispensáveis, pois a visualidade problematiza o conceito, e quando colocada em comparação àquilo que essa contrapõe o entendimento tornase mais claro. Uma vez retomada a leitura das obras selecionadas pelos alunos, o processo de ensino se direcionou para a compreensão que cada um ou o grupo tinha das linguagens que seriam trabalhadas (neste momento os alunos estudavam em sala de aula as possiblidades de intervenções artísticas).

Expostas as leituras das obras, voltaram as atenções para a aplicabilidade e ao conhecimento das linguagens e materiais que se dispunham a trabalhar - essa noção foi 
orientada dentro de questionamentos que afloraram durante as aulas regulares e as experiências-aulas: a condição efêmera da ação artística, o processo como obra, a criação coletiva, a intervenção no cotidiano e outras questões e dúvidas que afloraram à medida que se caminhavam com a proposta. Como pode-se ver nos relatório da professora em formação Thais Doro:

\begin{abstract}
Nessa fase não ficamos ligados somente ao nosso grupo, ajudávamos quem nos solicitava e isso fez com que os alunos tivessem que explicar suas ideias novamente e assim acabavam enxergando novas dúvidas. Todo o processo foi documentado pelos próprios alunos através de fotos e vídeos, foi enfatizado que além de registrarem o resultado final era muito importante registrarem o processo também. Com essa atividade observei que vários alunos que normalmente são apáticos e poucos interessados com propostas anteriores embarcaram com tudo, trazendo ideias, referências e ânimo, enquanto outros conseguiram se apoiar facilmente em projetos de amigos não fazendo quase nada e de última hora que acabou por não concluir a linha de raciocínio esperada. Mas apesar disso acredito que tivemos um bom aproveitamento.
\end{abstract}

Finalizada a parte expositiva, do segundo encontro até os momentos de execução, iniciou-se um mapeamento dos níveis de compreensão a partir de uma dinâmica prática que foi o elemento condutor de toda a problematização da experiência-aula. Sempre em grupos debatiam o trabalho proposto pelo colega, procuravam possibilidades e restrições de aplicabilidade destes trabalhos, gerando dúvidas e reorientando os projetos para algo palpável, concreto dentro da realidade escolar.

\title{
5 PRATICAR: ERROS E ACERTOS ESTÃO INSERIDOS NO PROCESSO
}

Esta etapa de trabalho intencionou propiciar aos alunos o amadurecimento dos códigos que pretendiam trabalhar. A percepção-apropriação se encarrega de estabelecer vivências estéticas intrínsecas ao universo adolescente - lúdicas, afetivas e experimentais -, ou seja, pretendeu-se que, essas, devidamente trabalhadas dentro do âmbito escolar, possibilitassem aos alunos, condicionar e codificar os sentidos estéticos de suas ações e consequentemente estabelecessem na intervenção uma ação comunicativa a sobrepor aos elementos meramente formais comuns em uma releitura no cotidiano escolar, tal como se percebe na descrição da ação realizada no relatório da professora em formação Thais Doro: 
Após essa explicação começamos a questioná-los sobre a obra escolhida, o que os atraiu nela, qual a relação deles com ela, quais as ideias para recriar a obra nos espaços propostos e o mais importante o que queriam passar com isso. No meu grupo houve uma predominância de meninas e senti facilidade pois, apesar de ser um grupo agitado (agitação normal de adolescentes) 80\% estavam realmente interessadas nessa primeira parte em que montamos o projeto de intervenção. Discutia individualmente os trabalhos mas, enquanto atendia um dos alunos os outros conversavam entre si sobre o projeto ou participavam da conversa comigo e o aluno atendido. Uma característica que gostei muito nesse grupo é que eles se ajudavam muito, mesmo alunos que não sabiam nem o que estavam fazendo ali os próprios colegas ajudavam a orientar ou ajudavam com que na elaboração do texto que eles deveriam fazer sobre o que eles fariam. Devido a essa empolgação surgiram ideias mirabolantes e que eles não conseguiriam executar, fizemos, os alunos e eu, adaptações nos seus projetos para que eles se tornassem executáveis. Mas essa empolgação também fez com que eles produzissem rápido, sendo que cerca de 3 aulas todos do grupo já tinham seus projetos estabelecidos.

$\mathrm{O}$ ensino de Arte centrado em elementos que transitam em suas linguagens possibilita aos indivíduos envolvidos no processo, uma abertura a novos códigos e padrões estéticos, modificando nestes, a sua relação com o meio que o envolve em uma ação de escolhas e interferências. Tal expectativa está imersa em um processo de amadurecimento e de trocas presentes na relação de ensino-aprendizagem. Voltar-se para as linguagens é possibilitar a experiência, enfatizar o processo e a construção cognitiva no aluno, vista desta forma, a ação do professor como mediador deste trabalho está presente em todas as etapas de ação: observação (fruição), reflexão-problematização, proposição-escolha-elaboração e interferência.

\section{APLICABILIDADE DE UMA PROPOSTA DE ENSINO SIGNIFICATIVO: ASPECTOS PEDAGÓGICOS DO FRUIR}

Ir a um espaço expositivo não é um ato passivo, mas sim de trocas. Trocas intersubjetivas, e é essa relação que é mediada no processo de construção de uma aula de Arte que tem a fruição como elemento inicial da experiência. A fruição é o encontro de subjetividades, a do artista, a do curador e a do público. Todos tem neste contato a experiência com aquilo proposto e presentificado na obra. A obra neste contato ganha vida, é algo próprio diverso da origem de sua concepção. 
Ana Mae (2008) considera esse contato extremamente significativo para o desenvolvimento estético do aluno. E, reitera que, é de suma importância que os professores ampliem os espaços de vivência dos alunos, e o museu (no caso de nossa realidade, a galeria da Divisão de Artes Plásticas da Universidade Estadual de Londrina) é o local que por excelência viabiliza uma mediação completa entre a obra e o olhar.

Estar diante do próprio objeto de arte, é ter materializado diante de si, problemas abstratos, muitas vezes distantes e irrelevantes para o aluno. A presença física do objeto (ou como queiram: obra), força o indivíduo, pela violência de sua presença, a criar ferramentas de apropriação. A estabelecer relações. É uma forma de contato de inteligibilidades.

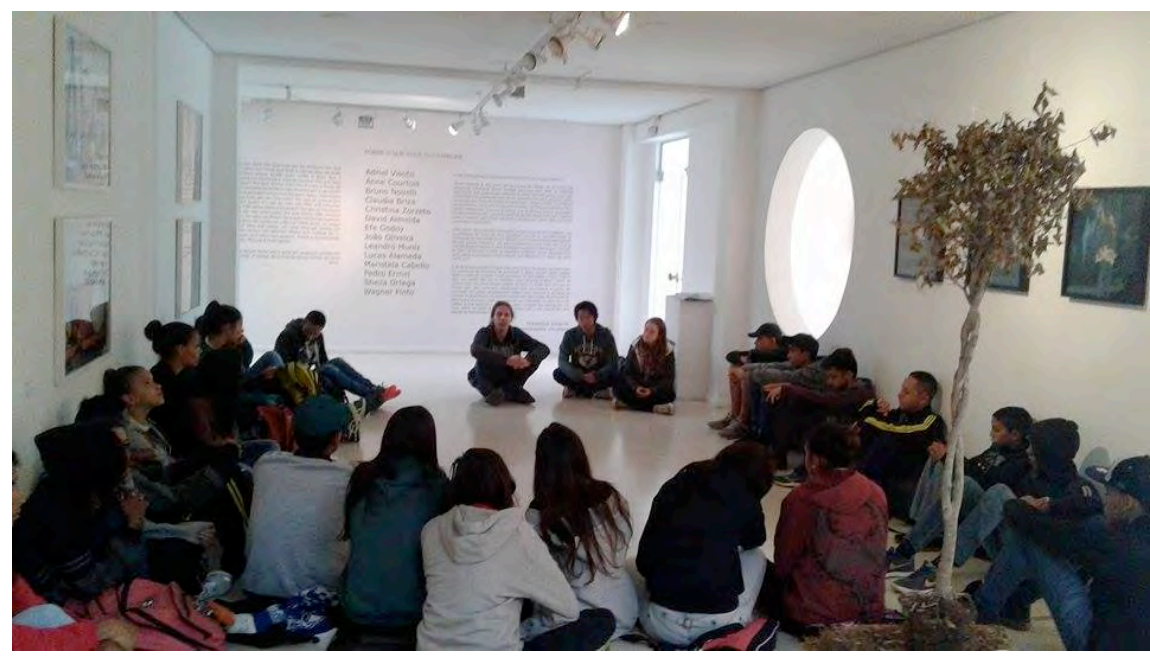

Fonte da imagem: PIBID-ARTES VISUAIS/ UEL

Imagem 03

Atividade de mediação desenvolvida pelos professores em formação durante visita dos alunos do primeiro ano do Ensino Médio.

Nesta perspectiva, tem-se a necessidade da mediação no espaço expositivo. E pensando o contato com a galeria da Dap-UEL ${ }^{5}$ como um momento de aprendizagem tanto na perspectiva do aluno da educação básica como do aluno de Licenciatura em Artes Visuais, esses se preparam para mediarem o contato dos adolescentes com o espaço. Assumiram o papel de apresentarem de forma coerente e pedagógica as obras expostas. Para isso fizeram uma aula preparatória com os mediadores da galeria na véspera da visita, obtiveram informações sobre artistas, obras e linguagens, como relata o professor em formação André H. Kikumoto:

\footnotetext{
${ }^{5}$ Os alunos fizeram a visita a Dap-UEL no dia 04/05/2016 com o intuito de observarem a exposição: Sobre o que pode ser familiar, inaugurada dia 15/04/16 com a curadoria de Cauê Alves e Danillo Villa.
} 
Voltamos a Divisão de Artes Plásticas (DAP) com os alunos do $1^{\circ} \mathrm{B}$, turma que não havia visitado a galeria. Diferentemente da primeira vez, nós professores em formação fomos os orientadores da atividade. Visitamos o local um dia antes (Stephanie, Vinicius e eu) para recebermos instruções e fazer uma busca de informações sobre os trabalhos em questão. Fomos recebidos pela estagiária, e, esta, nos instruiu com textos dos artistas presentes e exemplificações de visitas anteriores.

O primeiro movimento de mediação, foi expor aos alunos o tema que envolvia o conjunto de obras e artistas diversificados naquela exposição. Seguindo o método propositor, os professores em formação apresentavam os conceitos presentes nas obras e questionavam o conjunto de alunos, sempre à procura de associações. Essas associações se fizeram valer de forma mais intensa quando os alunos se espalharam pela galeria, explorando visualmente o espaço, selecionando obras e temas. A forma de abordagem está descrita no relatório de André H. Kikumoto:

Ao chegar, sentamos no chão do primeiro cômodo e dissertamos sobre o tema da exposição. Confesso que me falta dedicação em realmente estudar o conteúdo e traduzir para uma linguagem mais simplificada, levando a informação de forma compreensiva para determinada faixa etária. Depois, permitimos o passeio pelo local, a fim de observar os trabalhos expostos e preencher o caderno com anotações conforme a atividade proposta. Revezadamente andávamos pelos salões em busca de auxiliar e responder dúvidas dos alunos. Essa etapa durou aproximadamente 20 minutos. Após esse tempo de pesquisa, reunimos novamente no salão térreo e falamos um pouco de nossa fruição com os trabalhos do espaço.

Toda a visita foi previamente preparada em sala de aula, durante as aulas que prescindiam a visita, discutiu-se em sala de aula as linguagens artísticas e as novas mídias como suporte. Os alunos já haviam sido iniciados em trabalhos de análise e interpretação de imagens, assim como, haviam estudado os gêneros de representação presentes na exposição. Em sala de aula, foi-lhes entregue um roteiro de análise que lhes permitia transitar por todas as obras, selecionar a que mais lhe despertasse o interesse e assim, dedicar-se a refletir sobre a mesma. Esse questionário possuía perguntas que circulavam em cima da obra escolhida pelos alunos. "O que o autor quis dizer?" "O que você entendeu desta obra?" "Relacione o trabalho com a temática da exposição". Esses questionamentos, ao mesmo tempo em que viabilizavam entrar na obra a partir dos referenciais do próprio aluno, propiciava a criação de uma releitura do mesmo, uma apropriação dos códigos presentes na composição. 
Em meio ao deslocamento e a fruição das obras no espaço, muitos alunos escolheram as mesmas obras, geralmente obras cujo tema lhes era familiar (que envolviam preguiça, bagunça, desorganização). Ficaram concentrados no valor lúdico em suas leituras, deixando de pensar a etapa seguinte da proposta, na qual precisariam desenvolver uma produção de releitura.

Uma observação constante, presente nos relatórios dos professores em formação, estava diretamente relacionada aos limites de interpretação dos alunos. Muitas vezes literais sem se arriscar pelas metáforas propostas pelos artistas. Porém, essa limitação ao penetrar nas obras expostas, gerou uma abertura para o diálogo, para o espaço de mediação. Interpretações literais também são formas de interpretação, é um primeiro momento para a apropriação. Ao questionarem “o que é isso?” ou ao afirmarem “eu não entendi”, demonstram neste contato algum tipo de busca que necessitava de uma nova reaproximação. É nesta reaproximação que atua o professor em sua ação mediadora, “(...) iniciar de uma interpretação mais profunda vinha apenas depois que relacionavam a obra, o tema da exposição e seu nome", como afirma a professora em formação Thais Doro.

Imagem 04

Aluna M. A. após transitar pela galeria, escolheu a obra na qual se debruçaria em suas análises e proposições.

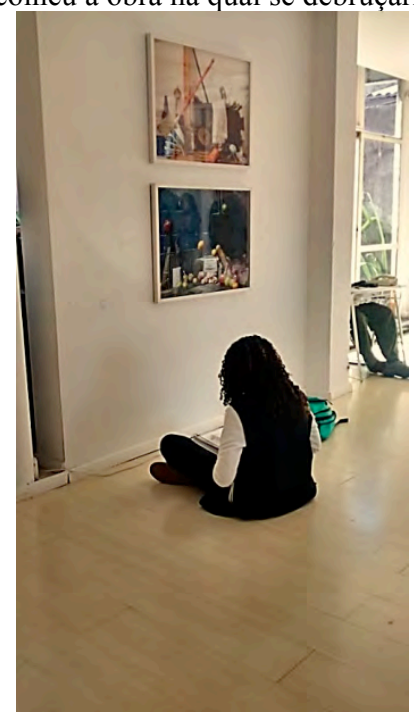

Fonte de imagem: PIBID-ARTES VISUAIS/ UEL

Nestas visitas ficou evidente que o contato com o espaço expositivo da Galeria se estabelecia em três estágios, nem sempre harmônicos, mas sempre presentes: 1) a observação 
do espaço como uma busca curiosa das informações visuais ali dispostas; 2) a mediação, o momento mais tenso do processo, pois é o trazer o aluno a uma ordem de raciocínio que exige dele a organização das informações recolhidas no primeiro contato.3) A exposição do contato com o objeto de arte momento que ocorre ainda na mediação, mas que se estende ao espaço escolar na forma de dúvidas e associações. Associações estabelecidas dentro do espaço expositivo, instigadas pela mediação que cumpre o seu papel de não dar respostas de nada, mas sim construir possibilidades, de relacionar conhecimentos, e tornar próximos os conhecimentos em contato. São diversas as observações que afloraram no contato:

Nossa! Isso é arte? Então eu também faço arte.

O que que é isso professor?

Que lindo! Mas o que ela quer dizer com essas palavras?

Porque que um cara junta objetos na rua?

Eu não entendi isso.

Fonte: PIBID-ARTES VISUAIS/ UEL - expressões presentes nos relatórios dos professores em formação.

Essas e outras observações mais construíam respostas que indagações. Memórias afetivas afloraram durante a mediação, não faltaram exemplos para relacionar aquilo que estava sendo exposto e os diversos contextos trazidos pelo conjunto de alunos.

\section{EXPERIÊNCIAS PLÁSTICAS: DA FRUIÇÃO À APROPRIAÇÃO/CRIAÇÃO}

Os alunos fizeram a visita a DAP no dia 04/05/2016 com o intuito de observarem a exposição: Sobre o que pode ser familiar, que inaugurou dia 15/04/16 com a curadoria de Cauê Alves e Danillo Villa. No dia foi proposto para os alunos que eles observassem as obras em exposição e que dentre todas escolhessem a que mais lhe chamava atenção, por motivos estéticos, emocionais, de afinidade com os materiais, etc., e a partir dessa escolha devem fazer preencher um questionário dado pelo professor supervisor André Camargo, que pergunta da catalogação e de como os alunos se identificaram com a obra.

Esse questionário teve como propósito iniciar os alunos ao tema de intervenção onde deveriam recriar o tema através das linguagens: vídeo performance, instalação, vídeo instalação, happening, lambe-lambe, interferência, áudio instalação e colecionismo. Essa interferência a partir da 
obra deveria ser feita na escola e no seu entorno, no bairro do aluno mora e no terminal de ônibus próximo a escola ${ }^{6}$.

Como visto no relato da professora em formação Thais Doro, todo o processo desenvolvido com os alunos tinha no contato destes com as obras expostas um momento de ruptura das linguagens, a possiblidade de expandir às reflexões sobre experiências estéticas e se inserir na prática, através das intervenções práticas estudadas. Neste sentido, o contato com as obras expostas, resultaria em releituras, não um mero exercício de se reproduzir aquilo que foi visto, mas sim, recriar a composição a partir de elementos presentes nas obras vivenciadas, somados aos elementos interpretantes que cada aluno trouxe para essa relação.

Visto desta forma, a releitura como ferramenta pedagógica é tomada como uma forma de apropriação da obra uma reinvenção na qual obra e fruidor se somam em um novo trabalho, ou seja, é a junção entre o universo simbólico do artista e do aluno neste processo de vivência. Neste sentido, como afirma Pillar (2008, p. 12), esta relação de trocas que ocorre durante o processo de fruição, interpretações são projetadas no conjunto de representações presentificadas nas obras, “(...) o olhar de cada um está impregnado com experiências anteriores, associações, etc. o que serve não é o dado real, mas aquilo que se quer captar e interpretar sobre o visto, o que nos é significativo" (PILLAR, 2008, p. 12-13).

É notório que cada indivíduo tem suas reações e leituras das obras, onde as ideias iniciais são sempre problematizadas a partir de universos particulares, hábitos, e as leituras realizadas por analogia, propiciando uma forma de compreensão imediata. Durante a experiência na Divisão de Artes Plásticas ${ }^{7}$ muitos alunos se identificaram com as pinturas de Adriel Visoto. Uma série de seis pinturas em óleo sobre tela de dimensões reduzidas (em média 20x30 centímetros), intitulada de "(in)permanência das coisas" As imagens mostram cômodos bagunçados, tomados por objetos desarranjados pelo espaço.

\footnotetext{
${ }^{6}$ Relatório de campo da professora em formação Thais Doro, 2016.

${ }^{7}$ Galeria de Artes Visuais da Universidade Estadual de Londrina, localizada na Avenida Juscelino Kubitschek, na região central do município.
} 
Imagem 05

Adriel Visoto. A (in) permanência das coisas \#04. Óleo sobre tela, 24 x 30 cm, 2014.

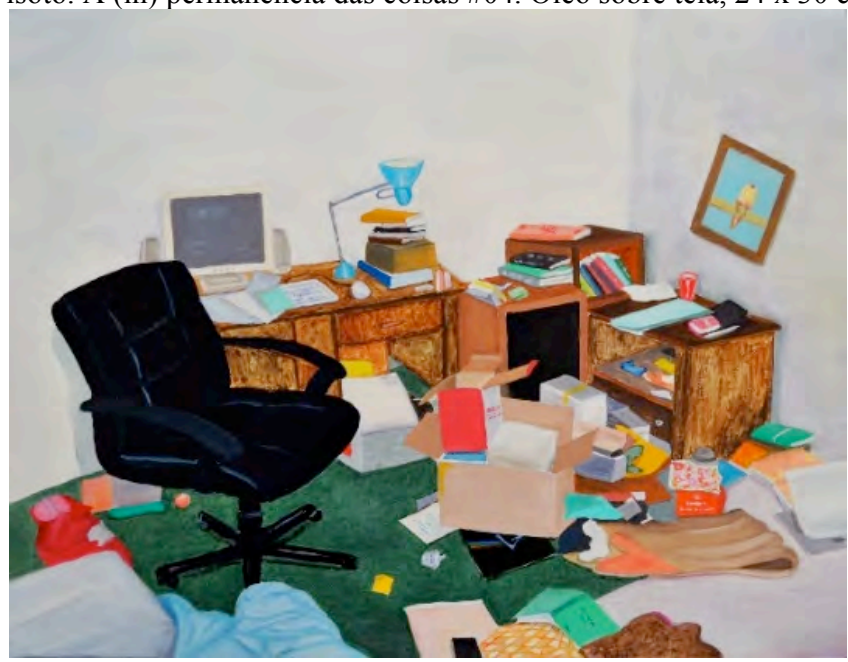

Fonte: http://adrielvisoto.blogspot.com.br/

Ao se depararem com o trabalho do artista diversos alunos associaram imediatamente com o seu comportamento em seus espaços: quartos, salas. A bagunça como uma assinatura, uma identidade, um traço de comportamento, como se pode ver nos relatos abaixo:

\section{Tabela II - ação seletiva por reconhecimento e familiaridade}

Eu escolhi essa obra pois, me identifiquei muito. Às vezes eu dedico muito o meu dia a leitura, tanto para lazer, quanto para trabalhos. Então eu fico tão focada na leitura que esqueço de arrumar meu quarto, por conta de falta de tempo. O quarto acaba ficando todo desorganizado. Uma verdadeira bagunça.

A.F.R, aluna do primeiro ano do Ensino Médio.

Fonte da tabela: PIBID/ André Camargo Lopes
O que me agradou na obra não foi

Escolhemos esta obra pelo fato de cotidiano de várias pessoas.

G.S.B. aluna do primeiro ano do Ensino Médio. muito pela bagunça em si, mas a bagunça que me faz bem e que faz falta.

L. S. M. aluna do primeiro ano do Ensino Médio.

Uma vez identificados com o artista, os alunos foram estimulados a recriarem o tema. Entre a fruição e a execução de suas releituras, diversas instâncias e situações se manifestaram em suas proposições:

"Intervenção: Colocar um varal no Igapó com roupas estendidas com café etc., tintas representando um lar uma família num lugar público". G.S.B. aluna do primeiro ano do Ensino Médio. 


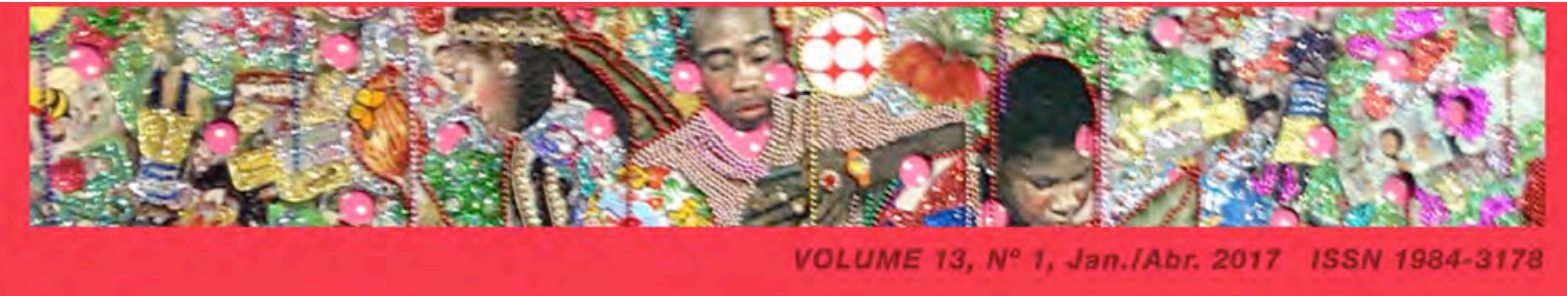

"Vamos intervir em um lugar público, com bagunça caseira e colocar um áudio instalação com som familiar". L. S. M. aluna do primeiro ano do Ensino Médio.

Foram muitas as ideias, porém, a produção visual pensada no ensino como um processo e não mero resultado, isso pode levar o próprio aluno durante os debates em grupo visualizar as possibilidades de execução: O como fazer; os materiais que têm à disposição; os locais possíveis de execução e o tempo hábil surgem como problemas que são solúveis nas frustrações geradas pela reflexão no projeto visual.

O professor nesta etapa atua como um propositor, um problematizador de situações. Sobre esse tema, a estimulamo-nos a reduzirem o espaço de atuação, visto que em nossas conversas, no referido material, a composição de origem no processo de criação sugeria performances. Optamos por vídeo performances focadas no deslocamento desta bagunça para um único ponto. Outro problema estabelecido: em qual local? Qual seria esse ponto? Decidimos pela biblioteca do colégio, utilizando as prateleiras de livros como elemento de fundo de uma das performances, enquanto que a outra performance o fundo seria neutralizado pela lona de projeção. Decidido os espaços faltava decidir a ação. "E se a bagunça voltasse contra vocês?"

Essa pergunta foi essencial para iniciarmos a criação da ação. Essa seria simples: em uma das vídeo performances a aluna-performer ficaria sentada frontalmente diante do fundo neutro. Impassível, enquanto um colega lhe arremessava as blusas recolhidas na turma. A outra performance seguiria o mesmo princípio, porém, seriam duas alunas-performers, uma diante da outra. Sentadas, como elementos passivos em uma ação de retorno de toda a bagunça.

Imagem 06

Vídeoperformance desenvolvido pelas alunas L.S.M. e G. S. B.

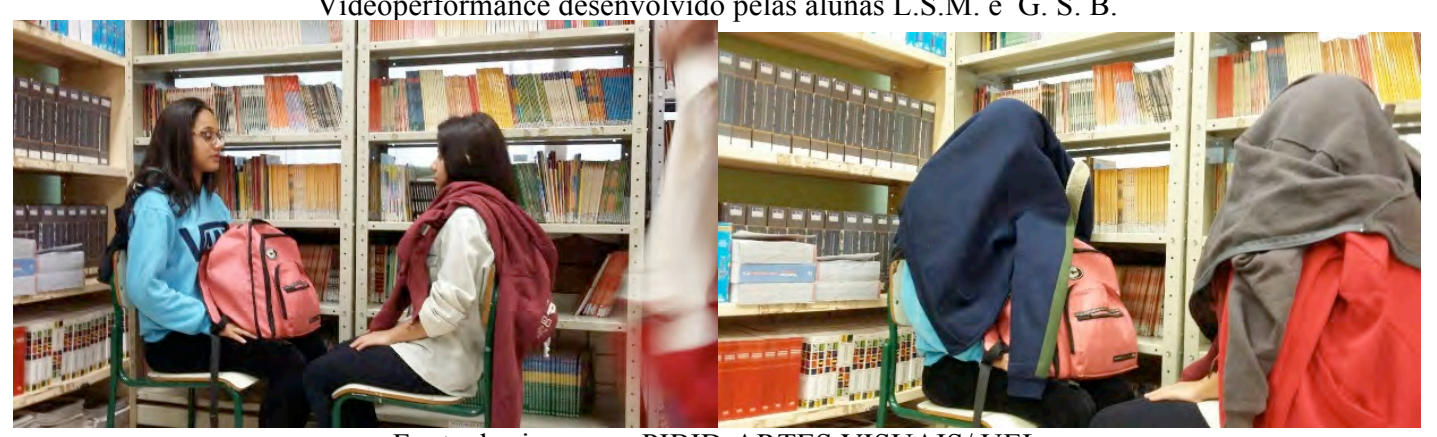

Fonte das imagens: PIBID-ARTES VISUAIS/ UEL 
Imagem 07

Vídeo performance da aluna A. F. R.

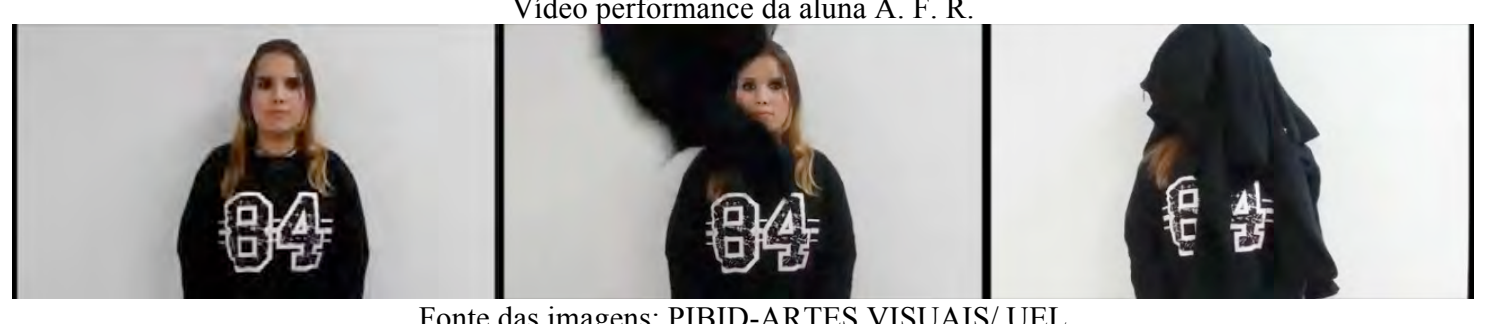

Fonte das imagens: PIBID-ARTES VISUAIS/ UEL

Sobre o mesmo tema houve o trabalho de intervenção com lambe-lambe de outra aluna. Essa avessa a bagunça representada nas pinturas de Adriel Visoto, se propôs a criar composições fotográficas de utensílios domésticos, organizados em grupos, sequenciados. Feito isso, a mesma os imprimiu em cores sobre papel sulfite e os colou nos postes das ruas que envolvem a escola.

Indistintamente estes trabalhos reorientavam o sentido original da obra de Adriel Visoto, recriavam-na a partir da descoberta de novas linguagens, de repertórios pessoais, atribuindo novos significados ao elemento inicial.

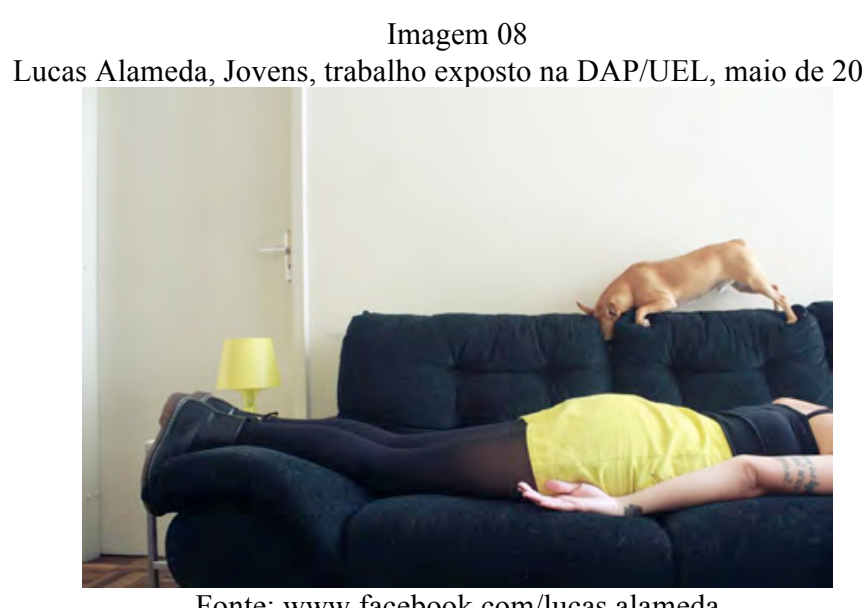

Fonte: www.facebook.com/lucas.alameda

Outro artista que despertou entre os alunos certa empatia por seus tema foi Lucas Alameda. Tratando do tédio como tema em um conjunto de cinco fotografias, todas de tamanho 40 x 60 centímetros, intituladas de "Jovens". Abriu margem para as mais diversas observações e leituras: 
Tabela III - diversas leituras possíveis sobre uma obra

\begin{tabular}{|c|c|}
\hline Aluno & Observação \\
\hline J. G. (18 anos) & $\begin{array}{l}\text { Preguiça. Eu achei interessante fica sentado no sofá no meio de todo mundo na hora do intervalo pra vê } \\
\text { o que as pessoas acham. Se eles acham legal, feio ou chato. }\end{array}$ \\
\hline $\begin{array}{l}\text { L. V. A. (15 } \\
\text { anos) }\end{array}$ & $\begin{array}{l}\text { Preguiça-desorganização-bagunça. Eu e meu grupo iremos a um ponto de ônibus com colchonete, roupas } \\
\text { e cobertores parando todos que passam pela rua, tirando fotos das reações das pessoas para mostrar a } \\
\text { preguiça a bagunça e a desorganização. }\end{array}$ \\
\hline $\begin{array}{ll}\text { A. } \\
\text { anos) }\end{array}$ & $\begin{array}{l}\text { Minha ideia primeiramente é pegar o sofá da sala dos professores e colocá-lo no pátio uns } 10 \text { minutos } \\
\text { antes do sinal bater. Quando os alunos descer eu já estarei sentada no sofá. Alguns vão se aproximar, } \\
\text { vão ficar curiosos e olhar estranhamente. Quando eles se aproximarem para sentar, eu encosto e grito } \\
\text { para eles saírem. } \\
\text { Mas porque isso? } \\
\text { Porque o sofá seria estranho no pátio onde não é seu lugar, porque seria estranho estar sentado nele. (...) } \\
\text { e com tudo isso uma pessoa estará filmando a ação, captando as expressões que o público vai ter. }\end{array}$ \\
\hline R. N. (16 anos) & $\begin{array}{l}\text { É uma imagem simples, mas é uma imagem que tem muita coisa que eu tenho muita convivência. Tem } \\
\text { uma garrafa de café. Eu gostei mais por causa do café. Porque eu gosto muito de café. É uma imagem } \\
\text { que lembra muito a casa de minha avó. Vou montar um piquenique no calçadão da UEL. }\end{array}$ \\
\hline N. A. (15 anos) & $\begin{array}{l}\text { Eu irei vir no recreio, vou fazer uma performance, irei usar uma carteira uma cadeira e um livro. No } \\
\text { recreio vou estar debruçada na mesa, tudo isso eu quero transmitir aos estudantes a questão que todos se } \\
\text { identificarão, quero dizer com tudo isso que os alunos sentem sono, preguiça. Eu vou fazer isso porque é } \\
\text { uma realidade dos estudantes, tem preguiça de estudar, especificamente em algumas matérias. }\end{array}$ \\
\hline V. R. (16 anos) & $\begin{array}{l}\text { Eu percebi que mais que ela ficou parada e o tempo foi passando e mais que ela ficava ali mais tempo ia } \\
\text { passando e as roupas sujando sem fazer nada. } \\
\text { Vamos intervir num shopping vou me cobrir e deitar em um lugar público como se eu estivesse em casa. } \\
\text { Sem fazer nada, só sendo folgado e vendo o tempo passar. }\end{array}$ \\
\hline
\end{tabular}

Fonte da tabela: PIBID/ André Camargo Lopes

O tédio proposto pelo artista transforma-se em preguiça. Ora uma preguiça decorrente do cansaço, ora uma sensação de descompromisso. Saíram da fotografia para as mais diversas propostas.

Imagem 09

Happening desenvolvido pela aluna N. A. a partir do trabalho de Lucas Alameda.

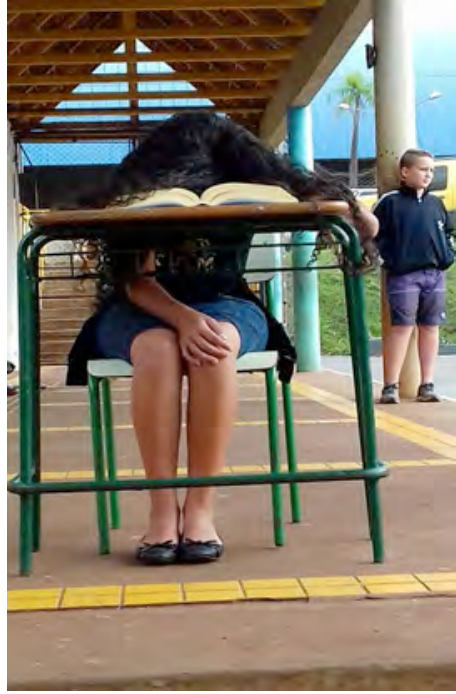

Fonte da Imagem: PIBID-ARTES VISUAIS/ UEL 
Entre os happenings e as instalações, os alunos mergulharam no universo criado nestas fotografias. E, das diversas propostas, conduziu-se a execução para locais aplicáveis, logo, entre a ideia inicial e a execução mudaram-se os espaço: o pátio do colégio transformou-se um "grande canteiro de happenings". Até a sala dos professores foi tomada pelos alunos.

\title{
8 RELEITURA, APROPRIAÇÃO = CRIAÇÃO
}

Se releitura é criação, essa se distancia e muito da cópia. Propor a releitura a um aluno é estabelecer ao mesmo que extraia de uma obra elementos que ele considere essenciais. Porém, o mesmo entenderá o que é essencial em uma obra somente com a vivência, com a experiência fruitiva e, por sua vez, a experiência fruitiva não se encerra com o final da visita, sequer se inicia com o momento do contato. Essa experiência ocorre dentro de um processo de ensino-aprendizagem, da descoberta de linguagens e leituras possíveis, que fica evidenciada nas observações presentes no relatório do professor em formação André $H$. Kikumoto:

\begin{abstract}
Outra produção interessante foi do aluno J. V. A priori o aluno não conseguia pensar em alguma criação a partir dos trabalhos expostos na divisão. Juntos, tentamos então desenvolver algo não a partir de um, mas sim a temática da exposição inteira, "Familiaridade". Associando o tema com uma situação pessoal, a morte recente de sua avó que tanto gostava, pensamos em um "baú de memórias". No processo, enquanto J. tentava escolher objetos que remetiam a lembranças de sua ente querida, ele cita uma pequena barra de ferro.

“Ah professor, tem uma barra lá em casa. Meu vô bebia muito, e quando chegava ele queria bater nela. Minha vó pegava essa barra de ferro e metia o cacete nele pra se defender."

Estava lá, um Ready-Made praticamente. Expliquei para o aluno então a importância do discurso numa produção contemporânea e contextualizei imediatamente com o trabalho do Duchamp. Nesse momento pude perceber um desenvolvimento estético em seu apreciar, compreendendo de verdade aquilo que estávamos desenvolvendo como produção artística.
\end{abstract}

A proximidade entre professor e aluno durante o processo de criação favoreceu o amadurecimento da proposta. Deste contato, entre as ideias, sugiram as seguintes proposições: 
$(25 / 05)$ Irei fazer videoinstalação dentro do meu quarto, filmarei a minha cama no escuro e com um reflexo da luz do abajur; para dar mais contraste negativo. Por exemplo, a noite quando deito para dormir penso nos meus avós; lembranças de saudades e algumas ruins que acontecem no dia a dia.

$(02 / 06)$ Irei fazer com caixa de isopor, irei trabalhar a temática saudade pelo fato de minha vó ter falecido recentemente irei trazer a maquete para o colégio, e deixarei.

(s/d) Um baú cheio de objetos de lembrança da minha vó não terá significado para as pessoas que olharem o trabalho, mas para mim sim, irei usar e organizar os objetos de forma que essa caixa seja um memorial do tempo em que minha vó estava viva. (eu quero trabalhar a saudade, e que as pessoas que verem essa caixa reflitam também as suas saudades.

Entre a ideia inicial e o resultado do trabalho existe um processo de construção muito intenso. Foi um mês de reflexão, no qual o aluno debatia com os professores em formação e com o próprio professor em sala. Havia um tema: saudade. Um objeto a barra de ferro. Existia uma vontade de torná-la um relicário. Faltava pensar os deslocamentos necessários. Em um primeiro momento, uma montagem, um ambiente para a barra. Tecido vermelho sobre uma mesa ampla e a barra foi registrada fotograficamente. Agora pensávamos, sobre a memória, uma representação; não era mais a barra que seria exposta, mas sim, o que representa. Uma fotografia com a história narrada em tiras de papel. Como suporte? Uma garrafa de vidro transparente. $\mathrm{O}$ aluno realmente se propôs a executar o trabalho. Suas ideias foram orientadas em torno do material que dispunha para executá-las.

Somente em um ambiente de aprendizagem no qual as linguagens são problematizadas e vivenciadas, é possível propor um trabalho de releitura. Problematizar a linguagem é colocar para o aluno a necessidade de se pesquisar materiais, ler a partir de seus códigos - sejam eles afetivos, lúdicos ou por analogia. Aranha (2008, p. 15) ao tratar do processo de criação afirma que, por um lado, é pautado pela “(...) busca [à] construção da linguagem artística é a incessante tentativa de compreensão e interpretação das interrogações que no mundo vivido, se desvelam em visualidades", por outro, no processo de ensino de Arte isso só é possível se o aluno for exposto aos problemas inerentes à linguagem para a qual é conduzido. 
Imagem 10

Assemblage realizada pelo aluno J. V. S. a partir do trabalho Vasos Comunicantes (2015) de Christina Zorzeto

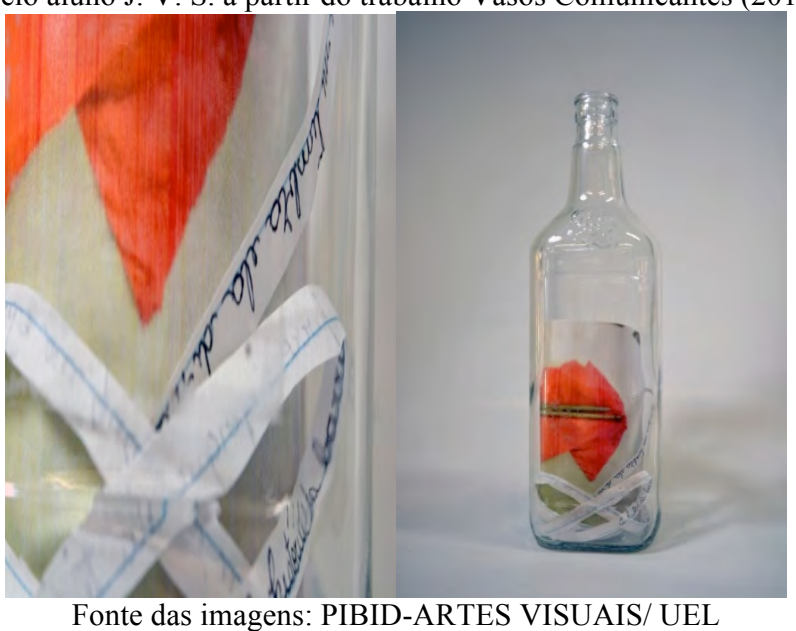

A apropriação do tema se inicia no contato, na dúvida gerada ainda na galeria, de maneira que toda forma de assimilação das obras foram coletivizadas, debatidas nos grupos que se formaram entorno dos trabalhos e posteriormente expostas durante as aulas. Assim, dos debates de produção à execução dos projetos artísticos, a ênfase das atividades recaem na prática coletiva, na interação e cooperação entre os grupos de alunos. Apostamos, desta forma, em um método de ensino voltado à construção coletiva, no qual o estranhamento (contato com a obra) é coletivizado no grupo, problematizado (tanto o tema, como a técnica e os signos presentes na obra) e em um último momento, propõe-se o jogo de recriar a partir de sua própria leitura. O processo de leitura e de organização das ações foi descrito da seguinte forma pelas alunas executoras:

Tabela IV - amostras do processo de leitura e organização de ação visual

\begin{tabular}{|c|c|c|}
\hline $\begin{array}{l}\text { De acordo com essa obra, eu fiz um } \\
\text { vídeo performance. Minha amiga } \\
\text { filmava e meu amigo jogava várias } \\
\text { roupas em mim. } \\
\text { Com esse vídeo performance queria } \\
\text { propor uma bagunça. } \\
\text { A.F.R, aluna do primeiro ano do } \\
\text { Ensino Médio. }\end{array}$ & $\begin{array}{l}\text { Colocamos uma de frente pra outra e } \\
\text { sentamos e depois o G. do } 1^{\circ} \mathrm{A} \text { foi } \\
\text { jogando várias coisas na gente em } \\
\text { representação a bagunça. } \\
\text { Filmagem: A. R. } 1^{\circ} \mathrm{A} \\
\text { Fotografia: M. } 3^{\circ} \mathrm{A} \\
\text { Escolhemos essa obra pelo fato de estar } \\
\text { no cotidiano de várias pessoas. } \\
\text { G.S.B, aluna do primeiro ano do } \\
\text { Ensino Médio. }\end{array}$ & $\begin{array}{l}\text { Colocamos uma cadeira de frente } \\
\text { para a outra e sentamos. O G. foi } \\
\text { jogando várias coisas na gente em } \\
\text { representação. } \\
\text { Filmagem: A. R. } 1^{\circ} \mathrm{A} \\
\text { Fotografia: M. } 3^{\circ} \mathrm{A} \\
\text { Escolhemos essa obra pelo fato de } \\
\text { estar no cotidiano de várias pessoas. } \\
\text { L. S. M. aluna do primeiro ano do } \\
\text { Ensino Médio. }\end{array}$ \\
\hline
\end{tabular}

Fonte da tabela: PIBID /André Camargo Lopes 
Do literal à provocação, os trabalhos surgiram de jogos entre o ler e o dizer, mediado pela presença do professor dentro do processo de criação. Logo, o professor, não é um elemento estranho ao trabalho, assim como os alunos é um executor, e como executor permite-se a refletir sobre os caminhos e objetivos dentro de cada projeto.

\section{CONSIDERAÇÕES FINAIS}

Dos 72 alunos que participaram da visita à DAP/UEL resultaram 30 trabalhos das mais diversas linguagens (vídeo performances, instalações, interferências com lambe-lambe, happenings, performances e vídeos). Muitos trabalhos foram realizados em grupos, devido à proximidade do tema e dos recursos gerados pelos próprios alunos. No geral, os trabalhos se dividiram em:

Tabela V - linguagens artísticas desenvolvidas durante o processo

\begin{tabular}{ll} 
Linguagem & Total de trabalhos desenvolvidos \\
\hline Happenings & 7 \\
\hline Vídeoperformances & 5 \\
\hline Instalações & 3 \\
\hline Vídeos & 1 \\
\hline Performance & 1 \\
\hline Intervenções com lambe-lambe & 9 \\
\hline $\begin{array}{l}\text { Intervenções - colecionismo, panfletagem, varal de } \\
\text { verbetes. }\end{array}$ & 3 \\
\hline Videoinstalação & 1 \\
\hline \multicolumn{2}{r}{ Fonte do quadro: PIBID/ André Camargo Lopes }
\end{tabular}

Essa ênfase em interferências cujas imagens mesmo que efêmeras, mantem-se como o resultado do processo (lambe-lambe), demonstra a dificuldade de se superar o universo formativo destes jovens, porém, ao convertê-las em uma ação resultante de uma leitura, expõe o aspecto afirmativo da apropriação temática. Neste sentido, em todos os trabalhos originários desse processo houve uma apropriação dos códigos problematizados pelos artistas em suas obras. As releituras se tornaram recriações, inserções interpretativas, e não meras reproduções. Por tudo isso, abandonar os suportes tradicionais, ou se distanciarem dos suportes originais das imagens, possibilitou aos alunos maior liberdade de ação e experiência com o lúdico como elemento comunicativo-estético. 


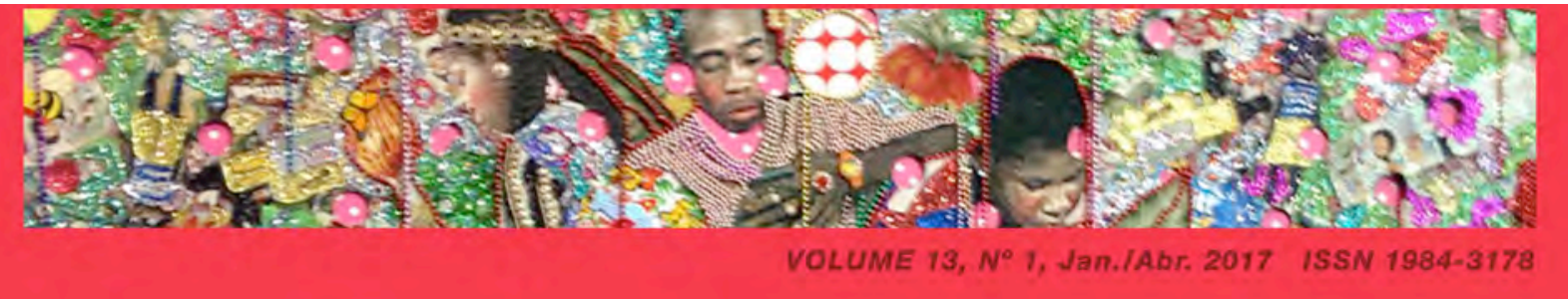

As ações de criação desenvolvidas pelos alunos no processo de ensino-aprendizagem não se resumem a um ponto de chegada. O processo em si se caracterizou como o objetivo maior do trabalho, em um método pautado no debate constante das proposições. No qual erros e acertos estão inseridos como elementos essenciais ao desenvolvimento da ideia. Em relação ao papel do professor, esse é o ponto central do processo, visto que a sua condição de problematizador - propositor de problemas, mediador entre a linguagem proposta e a interpretação do aluno, nesta perspectiva, o ato avaliativo está focado na apropriação do problema, nas diversas respostas que se organizam no tempo de construção da ação.

\section{REFERÊNCIAS}

ARANHA, Carmen S. G. Exercícios do Olhar. $1^{\text {a }}$ ed. São Paulo: Unesp; Rio de Janeiro: FUNARTE, 2008.

BARBOSA, Ana Mae e COUTINHO, Rejane Galvão. Arte/Educação como mediação cultural e social. São Paulo: Editora Unesp, 2008.

FERRAZ, Maria Heloisa C. de T. e FUSARI, Maria F. de Rezende. Arte na Educação Escolar. São Paulo: Cortez, 2010.

PARANÁ. Secretaria de Estado da Educação do. Diretrizes Curriculares de Arte para a Educação Básica. Curitiba - PR: Departamento de Educação Básica, 2008.

PILLAR, Analice Dutra. Leitura \& Releitura. Arte, Leitura e seu Ensino: Possibilidades Diversificadas Pedagógicas em Sala de Aula. Londrina: UEL, 2008. 